\title{
ANALISIS KEPUASAN KONSUMEN TERHADAP MINAT BELI PRODUK BUNGA MELATI(STUDI KASUS DESA TALKANDANG, KECAMATAN SITUBONDO, KABUPATEN SITUBONDO)
}

\author{
Fahris Abdurrahman Wahid ${ }^{1)}$ Puryantoro $^{2^{*}}$, \\ Fakultas Pertanian, Universitas Abdurachman Saleh Situbondo \\ *Email Korespondensi : puryantorounars@gmail.com
}

\begin{abstract}
Abstrak
Era globalisasi memunculkan banyak masalah dari segi persaingan bisinis yang semakin kompetitif termasuk di dalamnya sektor pertanian. Pemasaran produk pertanian sangat berbeda dengan berbagai produk lain sebab mudah rusak dan tidak tahan lama, karenanya para pelaku dibidang ini harus mempertimbangkan berbagai hal di dalam pemasaran yang berimbas pada kepuasan konsumen, dimana hal tersebut sangat menentukan minat beli konsumen. Bunga melati merupakan salah satu komoditas tanaman hias (folrikultura) berupa perdu berbatang tegak yang hidup menahun. Tanaman ini merupakan salahsatu tanaman yang dibudidayakan secrara intensif oleh sebagian petani di Desa Talkandang Kecamatan Situbondo Kabupaten Situbondo lebih dari 50 tahun lalu. Kepuasan konsumen merupakan faktor utama yang mempengaruhi timbulnya minat beli konsumen, karenaya variabel-variabel dalam kepuasan konsumen berupa kualitas produk, kualitas pelayanan, harga, inovasi produk, ketersediaan produk dan hubungan emosional merupakan aspek yang dikaji guna melihat pengaruhnya terhadap minat beli konsumen akan produk bunga melati di Desa Talkandang. Hasil penelitian menunjukkan bahwa variabel-variabel dalam kepuasan berupa berupa kualitas produk, kualitas pelayanan, harga, inovasi produk, ketersediaan produk dan hubungan emosional berpengaruh terhadap minat beli hanya secara simultan atau bersama-sama. Keenam variabel bebas tersebut mempengaruhi minat beli hanya secara simultan sebesar $35,3 \%$, sedangkan sisanya sebesar 64,7 \% dijelaskan oleh variabel lain di luar penelitian ini.
\end{abstract}

Kata Kunci : Pemasaran, Bunga Melati, Petani Desa Talkandang, Kepuasan Konsumen, Minat Beli.

\begin{abstract}
The globalization era has raised many problems in terms of increasingly competitive business competition, including in the agricultural sector. Marketing of agricultural products is very different from various other products because agricultural products are perishable and not durable. Therefore, actors in this field must consider various things in marketing that impact on customer's satisfaction and greatly determine customer's buying interest. Jasmine flower is one of the ornamental plant commodities (floriculture) in the form of erect stem trunks that live for years. This plant is one of the plants that was cultivated intensively by some farmers in Talkandang Village, Situbondo District, Situbondo Regency more than 50 years ago. Customeer's satisfaction is the main factor that influences the emergence of customer's buying interest, therefore the variables in costumer's satisfaction in the form of product quality, service quality, price, product innovation, product availability and emotional relationships are aspects that are studied in order to see their influence on customer's buying interest at jasmine flower products in Talkandang Village. The results showed that the variables in the form of satisfaction in the form of product quality, service quality, price, product innovation, product availability and emotional relationships influence buying interest only simultaneously or together. The six independent variables affect buying interest only simultaneously at 35.3\%, while the remaining $64.7 \%$ is explained by other variables outside of this study.
\end{abstract}


Keywords: Marketing, Jasmine Flowers, Talkandang Village Farmers, Customer's Satisfaction, Buying Interest

\section{PENDAHULUAN}

Pemasaran merupakan hal penting dan perlu mendapat perhatian lebih dalam bidang bisnis, karena pemasaran merupakan ujung tombak agar suatu produk barang atau jasa dapat memenuhi kebutuhan dan keinginan konsumen dengan tujuan memperoleh margin keuntungan bagi pihak produsen. Pemasaran produk pertanian seperti tanaman florikultura berupa bunga melati sangat berbeda dengan berbagai produk lainnya mengingat produk pertanian mudah rusak dan tidak tahan lama, karenanya para pelaku dibidang ini harus mempertimbangkan berbagai hal di dalam pemasaran yang berimbas pada kepuasan konsumen, dimana hal tersebut sangat menentukan minat beli konsumen.

Kotler dan Keller (2009) menyatakan bahwa "Kepuasan adalah perasaan senang atau kecewa seseorang yang muncul setelah membandingkan kinerja (hasil) produk yang dipikirkan terhadap kinerja yang diharapkan". Menurut Tjiptono (2012), kepuasan konsumen adalah situasi yang ditunjukkan oleh konsumen ketika mereka menyadari bahwa kebutuhan dan keinginannya sesuai dengan yang diharapkan serta terpenuhi secara baik. Sedangkan menurut Bachtiar (2011), kepuasan konsumen merupakan perasaan positif konsumen yang berhubungan dengan produk/jasa selama menggunakan atau setelah menggunakan jasa atau produk.

Menurut Kotler (2008), kualitas produk adalah karakteristik produk atau jasa yang tergantung pada kemampuannya untuk memuaskan kebutuhan pelanggan yang dinyatakan atau diimplikasikan. Sedangkan definisi kualitas produk menurut Tjiptono (2006) adalah suatu kondisi dinamis yang berhubungan dengan produk, jasa, manusia, proses, dan lingkungan yang memenuhi atau melebihi harapan. Kualitas sering dianggap sebagai ukuran relatif kebaikan suatu produk atau jasa yang terdiri atas kualitas desain dan kualitas kesesuaian.

Kualitas pelayanan (service quality) merupakan konsep yang abstrak dan sukar dipahami, karena kualitas pelayanan memiliki karakteristik tidak berwujud, bervariasi, serta tidak tahan lama (Tjiptono, 2002).

Kualitas pelayanan merupakan tingkat keunggulan yang diharapkan dan pengendalian atas tingkat keunggulan tersebut untuk memenuhi keinginan pelanggan. Ada dua faktor yang mempengaruhi kalitas pelayanan, yaitu pelayanan yang diharapkan (expected service) dan pelayanan yang diterima (perceived service). Kepuasan pelanggan dipengaruhi oleh kualitas pelayanan, dalam hal ini kualitas pelayanan terdiri dari bukti fisik, keandalan, daya tanggap, jaminan, dan empati.

Menurut Harini (2008) harga merupakan nilai uang yang seseorang butuhkan untuk memperoleh sejumlah produk dan pelayanan, karenanya peranan harga tak lepas dari proses jual beli suatu produk atau jasa. Harga membantu konsumen untuk menentukan seseorang akan membeli barang atau tidak. Bagaimana konsumen memandang harga tertentu baik tinggi, rendah maupun wajar mempunyai pengaruh yang kuat terhadap maksud membeli dan kepuasan. Sebagai contoh dalam hal persepsi kewajaran harga dimana pada umumnya konsumen memberikan perhatian pada harga yang dibayar oleh konsumen lain.

Menurut Nelly dkk (2001) bahwa, inovasi produk menunjukan pada pengembangan dan pengenalan produk baru atau di kembangkan yang berhasil dipemasaran. Inovasi produk dapat berupa perubahan desain, komponen dan arsitektur produk. Thomas (2008) mengatakan bahwa, inovasi produk merupakan satu hal yang potensial untuk menciptakan pemikiran dan imajinasi orang yang pada akhirnya menciptakan pelanggan. Menurut Dourgherty (1996) bahwa, inovasi produk merupakan 
suatu cara yang penting bagi perusahaan agar tetap dapat beradaptasi dengan pasar, teknologi, dan persaingan.

Distribusi adalah saluran yang digunakan sebuah perusahaan untuk menyalurkan barang ke konsumen. Tujuan strategi ini adalah untuk mencapai kepuasan jumlah pelanggan yang optimal pada waktu yang tepat. Semakin produk tersebut sesuai yang dijadwalkan dalam ketersediaannya maka akan mempengaruhi intensitas pembelian konsumen. Hal ini sesuai dengan pernyataan Kotler (2005) bahwa salah satu faktor yang mempengaruhi minat beli konsumen adalah faktor ketersediaan produk.

Tjiptono (2005) mempunyai pendapat bahwa untuk mengukur kepuasan konsumen adalah dengan kemudahan. Kemudahan yang dimaksud adalah kemudahan untuk mendapatkan produk atau jasa. Ketersediaan produk juga akan memudahkan konsumen untuk mendapatkan produk yang diinginkannya. Pelanggan akan semakin puas apabila produk mudah dijangkau dan selalu tersedia untuk dibeli konsumen.

Menurut Zeithaml dan Bitner (2012) hubungan emosi adalah suasana hati. Suasana hati yang sedang gembira cenderung akan berpengaruh terhadap respon atau persepsi yang positif terhadap produk atau jasa yang diberikan, sebaliknya suasana hati atau emosi yang buruk, maka emosi tersebut akan membawa respon atau persepsi yang negatif terhadap produk atau jasa yang diberikan.

Menurut Kotler (2005) minat beli adalah sesuatu yang timbul setelah menerima rangsangan dari produk yang dilihatnya, dari sana timbul ketertariakan untuk mencoba produk tersebut sampai pada akhirnya timbul keinginan untuk membeli agar dapat memilikinya. Sedangkan menurut Keller (1998), minat beli konsumen adalah seberapa besar kemungkinan konsumen membeli suatu merek atau seberapa besar kemungkinan konsumen untuk berpindah dari satu merek ke merek lainnya.

Berdasarkan penjabaran kepuasan konsumen di atas, akan sangat penting untuk mengetahui variabel-variabel penentu dalam kepuasan konsumen terhadap minat beli yang perlu dipahami oleh setiap pelaku usaha, guna memuaskan kebutuhan serta keinginan konsumen dan dapat meningkatkan keunggulan dalam persaingan pasar. Adapun variabel penentu yang digunakan dalam menilai kepuasan konsumen menurut Irwan (2008) variabel-variabel dalam kepuasan konsumen terdiri dari aspek kualitas produk, kualitas pelayanan, harga, kemudahan mendapat produk serta emosi. Setelah disesuaikan dengan kondisi lapang, maka peneliti menetapkan variabel-variabel dalam kepuasan terdiri dari enam aspek yang perlu diperhatikan, yaitu:

Tujuan Penelitian untuk mengetahui pengaruh yang ditimbulkan variabel-variabel dalam kepuasan konsumen berupa kualitas produk, kualitas pelayanan, harga, inovasi produk, ketersediaan produk dan hubungan emosional terhadap minat beli konsumen akan produk bunga melati yang dihasilkan oleh para petani di Desa Talkandang Kecamatan Situbondo Kabupaten Situbondo.

\section{METODE PENELITIAN}

\section{Lokasi dan Waktu Penelitian}

Penelitian ini dilakukan di Desa

Talkandang, Kecamatan Situbondo, Kabupaten Situbondo, Provinsi Jawa Timur. Pemilihan lokasi dilakukan secara Purposive dengan pertimbangan bahwa daerah tersebut merupakan sentra produksi bunga melati di Kabupaten Situbondo. Pengumpulan data dilakukan selama bulan Februari - Maret 2018.

\section{Populasi}

Populasi merupakan kumpulan individu atau objek penelitian yang memiliki kualitas serta ciri-ciri yang telah ditetapkan. Setelah melakukan observasi. Populasi pada penelitian ini terdiri dari 32 petani di Desa Talkandang. Sedangkan untuk populasi 
konsumen yang juga merupakan sumber dalam memperoleh data untuk penelitian ini adalah sebanyak 164 orang, yang seluruhnya didapat dari rekomendasi para petani dengan kriteria konsumen yang direkomendasikan adalah jenis konsumen yang membeli produk bunga melati dengan tujuan pemakaian sebagai dekorasi atau sebagai bahan baku bunga ronce serta pembelian minimal dilakukan setiap tahun dalam kurun waktu pembelian selama tiga tahun terakhir.

\section{Sampel}

Penarikan konsumen sampel dari produk bunga melati menggunakan teknik purposive sampling, yaitu teknik penentuan sampel dengan pertimbangan tertentu (Sugiyono, 2013) dengan teknik penentuan sampel untuk tujuan mengetahui kepuasan mereka terhadap produk bunga melati di Desa Talkandang.

Sampel ditentukan berdasarkan pada perhitungan dari rumus Slovin dengan tingkat kesalahan yang ditoleransi sebesar 10\% (Umar Husein 2003).

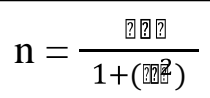

Keterangan :

$\mathrm{n}=$ Ukuran Sampel N = Ukuran Populasi

e $=$ Persen kelonggaran ketidaktelitian karena kesalahan pengambilan sampel yang masih dapat ditolerir atau diinginkan, sebanyak $10 \%$.

Berdasarkan rumus tersebut, maka jumlah konsumen sampel yang diambil dalam penelitian ini adalah:

$\mathrm{n}=\frac{164}{1+164\left(10 \%^{2}\right)}$

$\mathrm{n}=\frac{164}{2,64}$

$\mathrm{n}=62,12=62$ konsumen sampel

Jumlah konsumen sampel yang digunakan dalam penelitian ini sebanyak 62 responden, dengan kriteria konsumen yang dipilih adalah konsumen yang membeli produk tersebut dengan tujuan pemakaian sebagai dekorasi atau sebagai bahan baku bunga ronce serta pembelian minimal dilakukan setiap tahun dalam kurun waktu pembelian selama tiga tahun terakhir.

\section{Teknik Pengumpulan Data}

Dalam suatu penelitian, metode pengumpulan data merupakan suatu faktor yang penting, karena penghitungan diperoleh dari data yang didapatkan dalam penelitian. Metode yang digunakan dalam pengumpulan data pada penelitian ini adalah pengamatan, wawancara, kuisioner, dan dokumentasi.

\section{Metode Analisis Data}

Sehubungan dengan masalah yang dikemukakan sebelumnya, maka akan dilakukan analisa berdasarkan data yang diperoleh dengan menggunakan peralatan analisis sebagai berikut: 


\section{Uji Validitas}

Uji validitas dalam penelitian ini digunakan untuk menguji kevalidan kuesioner. Validitas menunjukkan sejauh mana ketepatan dan kecermatan suatu alat ukur dalam melakukan fungsi alat ukurnya. Uji validitas digunakan untuk mengetahui valid atau tidaknya suatu kuesioner. Suatu kuesioner dikatakan valid jika pertanyaan pada kuesioner mampu mengungkapkan suatu yang akan diukur oleh kuesioner tersebut (Ghozali, 2005).

Kriteria pengambilan keputusan valid tidaknya suatu kuesioner menurut Sugiyono, (2009) adalah sebagai berikut:

a. Jika $r_{\text {hitung }} \geq r_{\text {tabel }}$, maka item-item pernyataan dari kuesioner adalah valid.

b. Jika $r_{\text {hitung }}<r_{\text {tabel }}$, maka item-item pernyataan dari kuesioner adalah tidak valid.

c. $\mathrm{r}$ tabel diperoleh dari $d f=n-2$ dengan tingkat signifikansi $95 \%$ atau $\alpha: 5 \%$ dimana: $\mathrm{df}$ : degree of freedom

$$
\mathrm{n} \text { : jumlah sampel }
$$

Uji validitas dalam penelitian ini menggunakan korelasi Product Moment menurut Sugiyono (2009) dengan rumus sebagai berikut:

$$
r_{x y}=\frac{n \Sigma X Y-\Sigma X \Sigma Y}{\sqrt{n \Sigma X^{2}}-(\Sigma X)^{2} \sqrt{n \Sigma Y^{2}-(\Sigma Y)^{2}}}
$$

Keterangan:

$r x y=$ Korelasi antar $X$ dan $Y$

$n=$ Jumlah responden

$X \quad=$ Skor masing-masing pertanyaan

$Y \quad=$ Skor total

Uji Reliabilitas

Menurut Sugiyono (2004) uji reliabilitas adalah data untuk mengukur suatu kuesioner yang merupakan indikator dari variabel atau konstruk. Suatu kuesioner dikatakan reliabel atau handal jika jawaban seseorang terhadap pernyataan adalah konsisten atau stabil dari waktu ke waktu. Setiap alat pengukur seharusnya memiliki kemampuan untuk memberikan hasil pengukuran yang konsisten. Makin kecil kesalahan pengukuran, makin reliabel alat pengukur.

Teknik pengukuran reliabilitas yang digunakan adalah teknik Cronbach alpha dengan menggunakan koefisien $(\alpha)$ (Sugiyono, 2004), yaitu:

$$
r_{11}=\left(\frac{k}{k-1}\right)\left(1-\frac{\Sigma \sigma^{2}}{\sigma 1^{2}}\right)
$$

$k \quad=$ Banyaknya butir pertanyaan

$\Sigma \sigma \sigma^{2}=$ Jumlah ragam butir

$\sigma \sigma 1^{2}=$ Jumlah ragam total

SPSS (Statistical Package for Social Sciences) juga memberikan fasilitas untuk mengukur realibilitas dengan uji statistik Cronbach Alpha $(\alpha)$. Suatu konstruk atau variabel dikatakan reliabel jika nilai Cronbach Alpha $>0,70$, dan jika nilai Cronbach Alpha $<0,70$ maka suatu konstruk atau variabel dikatakan tidak reliabel (Ghozali, 2016).

\section{Analisis Regresi Linear Berganda}

Analisis ini digunakan untuk mengetahui seberapa besar pengaruh variabel-variabel bebas yaitu kualitas produk (X1), kualitas pelayanan (X2), Harga (X3), inovasi produk (X4) dan ketersediaan produk (X5) terhadap variabel terikat yaitu minat beli (Y) di Desa 
Talkandang Kecamatan Situbondo Kabupaten Situbondo. Menurut Sugiyono, (2010) untuk mengetahui pengaruh variabel bebas terhadap variabel terikat digunakan rumus analisis regresi linier berganda sebagai berikut:

$Y=$
$+\alpha+b_{1} x_{1}+b_{2} x_{2}+b_{3} x_{3}$
$+b_{4} x_{4}+b_{5} x_{5}+e$

Keterangan:

$\mathrm{Y} \quad=$ Minat Beli

$\mathrm{X}_{1} \quad=$ Kualitas Produk

$\mathrm{X}_{2} \quad=$ Kualitas Pelayanan

$\mathrm{X}_{3}=$ Harga

$\mathrm{X}_{4} \quad$ = Inovasi Produk

$\mathrm{X}_{5} \quad=$ Ketersediaan Produk

$\mathrm{X}_{6} \quad=$ Hubungan Emosional

$\alpha \quad=$ Konstanta

$b 1-b 5=$ Koefisien regresi

$e \quad=$ Toleransi ketidakaktifan/epsilon

\section{Variabel Bebas}

Variabel bebas (independent) adalah variabel yang dapat dimanipulasi oleh peneliti sesuai kebutuhan. Variabel bebas juga disebut sebagai variabel yang mempengaruhi variabel terikat (dependent), baik yang pengaruhnya positif maupun yang pengaruhnya negatif (Ferdinand, 2006).

Variabel bebas dalam penelitian ini terdiri dari enam variabel, yakni:

1. Kualitas Produk (X1)

2. Kualitas Pelayanan (X2)

3. Harga (X3)

4. Inovasi Produk (X4)

5. Ketersediaan Produk (X5)

6. Hubungan Emosional (X6)

\section{Variabel Terikat}

Variabel terikat merupakan variabel yang menjadi pusat perhatian peneliti (Ferdinand, 2006). Variabel terikat adalah variabel yang dipengaruhi akibat dari adanya variabel bebas, dikatakan sebagai variabel terikat karena nilainya tergantung pada variabel lain, dimana nilainya akan berubah jika variabel yang mempengaruhinya berubah. Variabel terikat dalam penelitian ini adalah minat beli (Y).

\section{Pengujian Secara Simultan (Uji F)}

Uji F digunakan untuk menguji hipotesis nol bahwa koefisien determinasi majemuk dalam populasi, R2 sama dengan nol. Uji signifikansi meliputi pengujian signifikansi persamaan regresi secara keseluruhan serta koefisien regresi parsial spesifik. Uji keseluruhan dapat dilakukan dengan menggunakan statistik F. Kemudian untuk menguji keberartian dari koefisien regresi secara simultan, digunakan pengujian statistik uji $\mathrm{F}$ dengan formulasi sebagai berikut (Gujarati, 2000):

$$
\mathrm{Uji} \mathrm{F}=\frac{r^{2} / k}{\left(1-R^{2}\right) /(n-k-1)}
$$


Keterangan:

$\mathrm{F}=$ Diperoleh dari tabel distribusi

$\mathrm{k}=$ Jumlah variabel bebas

$\mathrm{R}^{2}=$ Koefisien determinasi ganda

$\mathrm{n}=$ Jumlah sampel Jumlah variabel bebas

Dasar pengambilan keputusan (Ghozali, 2005):

a. Dengan membandingkan nilai $\mathrm{F}$ hitung dengan $\mathrm{F}$ tabel

1) Apabila F hitung $\geq \mathrm{F}$ tabel, maka hipotesis diterima, artinya variabel bebas secara simultan berpengaruh signifikan terhadap variabel terikat.

2) Apabila $F$ hitung < F tabel, maka hipotesis ditolak, artinya variabel bebas secara simultan tidak berpengaruh signifikan terhadap variabel terikat.

b. Dengan menggunakan angka probabilitas signifikansi

1) Apabila probabilitas signifikansi $>0,05$, maka hipotesis ditolak, artinya variabel bebas secara simultan tidak berpengaruh signifikan terhadap variabel terikat.

2) Apabila probabilitas signifikansi $<0,05$, maka hipotesis diterima, artinya variabel bebas secara simultan berpengaruh signifikan terhadap variabel terikat.

Penentuan nilai $\mathrm{F}$ tabel diperoleh dari:

$$
\begin{aligned}
& \mathrm{dfN} 1=\mathrm{k}-1 \\
& \mathrm{dfN} 2=\mathrm{n}-\mathrm{k}
\end{aligned}
$$

keterangan:

$\mathrm{df}=$ degree of freedom

$\mathrm{n}=$ jumlah sampel

$\mathrm{k}=$ jumlah variabel (bebas dan terikat)

\section{Pengujian Secara Parsial (Uji t)}

Uji t digunakan untuk menguji signifikansi hubungan antara variabel $\mathrm{X}$ dan variabel $\mathrm{Y}$, apakah variabel X1, X2, X3, X4 dan X5 benar-benar berpengaruh terhadap variabel Y. Menurut Sugiyono (2004) formulasi perhitungan uji t adalah sebagai berikut:

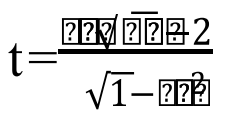

Keterangan:

$\mathrm{t}=$ Nilai hitung

$\mathrm{r}=$ Koefisien korelasi

$\mathrm{n}=$ Banyaknya observasi

Dasar pengambilan keputusan (Ghozali, 2005):

a. Dengan membandingkan nilai t hitungnya dengan $t$ tabel, dengan tingkat signifikansi $95 \%$ atau $\alpha 5 \%$.

1) Apabila $t$ hitung $\geq t$ tabel atau $-t$ hitung $\leq-t$ tabel, maka hipotesis diterima, artinya variabel bebas secara parsial berpengaruh signifikan terhadap variabel terikat.

2) Apabila $t$ hitung $<t$ tabel atau - $t$ hitung $>-t$ tabel, maka hipotesis ditolak, artinya variabel bebas secara parsial tidak berpengaruh signifikan terhadap variabel

$$
\mathrm{Kd}=\mathrm{r}^{2} \times 100 \%
$$


terikat.

b. Dengan menggunakan angka probabilitas signifikansi.

1) Apabila angka probabilitas signifikansi $>0,05$, maka hipotesis ditolak, artinya variabel bebas secara parsial tidak berpengaruh signifikan terhadap variabel terikat.

2) Apabila angka probabilitas signifikansi $<0,05$, maka hipotesis diterima, artinya variabel bebas secara parsial berpengaruh signifikan terhadap variabel terikat.

Penentuan nilai t tabel berdasarkan taraf signifikansi sebesar 95\% dan taraf derajat kebebasan

Keterangan :

$$
(d f)=n-k(\alpha / 2) .
$$

Df $=$ degree of freedom $n=$ jumlah sampel

$\mathrm{k}=$ jumlah variabel (bebas dan terikat)

$\alpha=5 \%$

\section{Koefisien Determinasi}

Koefisien determinan merupakan besaran yang memberikan informasi mengenai proposi variasi dalam variabel terikat oleh variabel bebas (Gujarati, 2006). Uji statistik R2 dapat dicari dengan rumus:

$$
\mathrm{d}=\mathrm{r}^{2} \mathrm{x} \cdot \mathrm{d} / \mathrm{h}
$$

Keterangan:

$\mathrm{Kd}=$ Koefisien determinan

$r \quad=$ Koefisien korelasi

Dimana Apabila:

a. $K d=0$, berarti pengaruh variabel $X$ terhadap variabel $Y$, lemah.

b. $K d=1$, berarti pengaruh variabel $X$ terhadap variabel $Y$, kuat.

Koefisien determinasi (Kd) pada intinya mengukur seberapa jauh kemampuan model dalam menerangkan variasi variabel terikat.

Nilai koefisien determinasi berada di antara nol dan satu. Nilai Kd yang kecil berarti kemampuan variabel-variabel bebas dalam menjelaskan variabel terikat amat terbatas. Kesimpulan hipotesis dilakukan berdasarkan t-test dan F-test untuk menguji signifikansi variabel-variabel bebas terhadap variabel terikat.

\section{HASIL DAN PEMBAHASAN Uji Validitas}

Berdasarkan data dari penghitungan yang telah dilakukan, maka dapat diketahui bahwa seluruh item pertanyaan dari masing-masing variabel adalah valid, sebab nilai koefisien korelasinya lebih besar dari $r$ tabel pada taraf signifikan $\alpha=5 \%$ yaitu 0,2500 . Maka dapat disimpulkan dari hasil uji validitas dapat dinyatakan bahwa seluruh item pertanyaan dalam kuisioner dapat dipercaya untuk mengambil data penelitian, dengan rincian hasil penghitungan yang dapat dilihat melalui tabel berikut : 
Tabel 1. Hasil Uji Validitas

\begin{tabular}{clccc}
\hline Variabel & Item & rhitung & rtabel & Keterangan \\
\hline Kualitas Produk & X1.1 & 0,771 & 0,2500 & Valid \\
(X1) & X1.2 & 0,736 & 0,2500 & Valid \\
& X1.3 & 0,695 & 0,2500 & Valid \\
& X1.4 & 0,737 & 0,2500 & Valid \\
Kualitas Pelayanan & X1.5 & 0,814 & 0,2500 & Valid \\
(X2) & X2.7 & 0,746 & 0,2500 & Valid \\
& X2.8 & 0,795 & 0,2500 & Valid \\
Harga & X3.9 & 0,854 & 0,2500 & Valid \\
(X3) & X3.10 & 0,858 & 0,2500 & Valid \\
& X3.11 & 0,879 & 0,2500 & Valid \\
Inovasi Produk & X4.12 & 0,877 & 0,2500 & Valid \\
(X4) & X4.13 & 0,864 & 0,2500 & Valid \\
& X4.14 & 0,918 & 0,2500 & Valid \\
Ketersediaan Produk (X5) & X5.15 & 0,782 & 0,2500 & Valid \\
& X5.16 & 0,832 & 0,2500 & Valid \\
\hline
\end{tabular}

\section{Uji Reliabilitas}

Berdasarkan penghitungan yang telah dilakukan, maka dapat diketahui bahwa nilai koefisien Cronbach Alpha seluruh variabel dalam penelitian ini adalah $>0,6$. Suatu variabel dapat dikatakan reliable jika nilai Cronbach Alpha lebih besar dari 0,6. Sehingga dapat disimpulkan bahwa dari hasil pengujian yang sudah dilakukan dinyatakan bahwa data yang telah diuji sudah reliabel, seperti hasil penghitungan yang ditunjukkan melalui tabel berikut:

Tabel 2. Hasil Uji Reliabilitas

\begin{tabular}{lccc}
\hline \multicolumn{1}{c}{ Variabel } & $\begin{array}{c}\text { Nilai Hitung } \\
\text { Alpha }\end{array}$ & Cronbach Alpha & Keterangan \\
\hline Kualitas Produk (X1) & 0,806 & 0,6 & Reliabel \\
Kualitas Pelayanan (X2) & 0,714 & 0,6 & Reliabel \\
Harga (X3) & 0,831 & 0,6 & Reliabel \\
Inovasi Produk (X4) & 0,860 & 0,6 & Reliabel \\
Ketersediaan Produk (X5) & 0,718 & 0,6 & Reliabel \\
Hubungan Emosional (X6) & 0,794 & 0,6 & Reliabel \\
Minat Beli (Y) & 0,710 & 0,6 & Reliabel \\
\hline
\end{tabular}

\section{Uji Regresi Linier Berganda}

Penghitungan regresi menggunakan program statistik SPSS Statistics 23.0 antara kualitas produk, kualias pelayanan, harga, inovasi produk, ketrsediaan produk dan hubungan emosional terhadap minat beli konsumen dapat dilihat melalui tabel berikut: 
Tabel 3. Hasil Uji F (ANOVA) Variabel-Variabel Yang Berpengaruh Terhadap Minat Beli Konsumen Akan Produk Bunga Melati di Desa Talkandang.

\begin{tabular}{|c|c|c|c|c|c|c|}
\hline & Model & Sum of Squares & Df & Mean Square & $\mathrm{F}$ & Sig. \\
\hline 1 & Regression & 79.733 & 6 & 13.289 & 6.555 & $.000^{\mathrm{b}}$ \\
\hline & Residual & 111.509 & 55 & 2.027 & & \\
\hline & Total & 191.242 & 61 & & & \\
\hline
\end{tabular}

a. Dependent Variable : Minat Beli

a. Predictors : (Constant), Kualitas Produk, Kualitas Pelayanan, Harga, Inovasi Produk, Ketersediaan Produk, Hubungan emosional

Hasil data diperoleh nilai $\mathrm{F}$ hitung sebesar 6,555 lebih besar dari $\mathrm{F}$ tabel sebesar 2,27 (F hitung > F tabel). Hali ini menunjukkan bahwa hipotesis yang menyatakan "Seluruh variabel dalam kepuasan konsumen berupa kualitas produk, kualitas pelayanan, harga, inovasi produk, ketersediaan produk dan hubungan emosional berpengaruh signifikan terhadap minat beli produk bunga melati di Desa Talkandang, Kecamatan Situbondo, Kabupaten Situbondo" diterima.

Secara berasama-sama seluruh variabel bebas (kualitas produk, kualitas pelayanan, harga, inovasi produk, ketersediaan produk, hubungan emosional) berpengaruh terhadap minat beli konsumen akan produk bunga melati di Desa Talkandang pada taraf kepercayaan 95\%.

Besarnya parameter variabel-variabel yang berpengaruh terhadap minat beli konsumen akan produk bunga melati di Desa Talkandang dapat diketahui melalui nilai determinasi $\left(\mathrm{R}^{2}\right)$. Koefisien determinasi berfungsi untuk mengetahui berapa persen pengaruh yang diberikan variabel $\mathrm{X}$ secara simultan taerhadap variabel $\mathrm{Y}$, dan berikut adalah nilai determinasi yang dapat dilihat melalui tabel berikut:

Tabel 4. Nilai Determinasi ( $\left.\mathrm{R}^{2}\right)$ Model Summary ${ }^{\mathrm{b}}$

\begin{tabular}{|c|c|c|c|c|}
\hline Model & $\mathrm{R}$ & R Square & Adjusted R Square & $\begin{array}{l}\text { Std. Error of the } \\
\text { Estimate }\end{array}$ \\
\hline 1 & $0,646^{a}$ & 0,417 & 0,353 & 1,424 \\
\hline
\end{tabular}

Nilai Adjusted R Square sebesar 0,353 menunjukkan bahwa persentase minat beli konsumen terhadap produk bunga melati di Desa Talkandang dapat dijelaskan secara bersama-sama sebesar 35,3 \% oleh variabel kualitas produk, kualitas pelayanan, harga, inovasi produk, ketersediaan produk dan hubungan emosional, serta sebesar 64,7\% dijelaskan oleh variabel-variabel lain di luar model regresi dalam penelitian ini, yang memiliki pengaruh lebih besar terhadap minat beli konsumen terhadap produk bunga melati di Desa Talkandang dibandingkan dengan enam variabel yang telah diuji.

Pengaruh variabel bebas (kualitas produk, kualitas pelayanan, harga, inovasi produk, ketersediaan produk dan hubungan emosional) terhadap variabel terikat (minat beli) dapat dilihat dalam uraian berikut: 
Tabel 5. Hasil Analisi Regresi Linier Berganda Variabel-Variabel Yang Mempengaruhi Minat Beli Konsumen Akan Produk Bunga Melati di Desa Talkandang.

\begin{tabular}{lccccc}
\hline \multirow{2}{*}{ Model } & \multicolumn{2}{c}{$\begin{array}{c}\text { Unstandardized } \\
\text { Coefficients }\end{array}$} & $\begin{array}{l}\text { Standardized } \\
\text { Coefficients }\end{array}$ & T & Sig. \\
\cline { 2 - 6 } & B & Std. Error & Beta & & \\
\hline 1 (Constant) & 4,323 & 1,636 & & 2,644 & 0,011 \\
Kualitas Produk & 0,134 & 0,089 & 0,251 & 1,499 & 0,140 \\
Kualitas Pelayanan & 0,098 & 0,092 & 0,126 & 1,063 & 0,292 \\
Harga & $-0,074$ & 0,089 & $-0,089$ & $-0,832$ & 0,409 \\
Inovasi Produk & 0,043 & 0,089 & 0,058 & 0,480 & 0,633 \\
Ketersediaan Produk & 0,130 & 0,111 & 0,151 & 1,172 & 0,246 \\
Hubungan Emosional & 0,215 & 0,145 & 0,240 & 1,485 & 0,143 \\
\hline
\end{tabular}

a. Dependent Variable: Minat Beli

\section{Kualitas Produk}

Nilai koefisien regresi kualitas produk adalah sebesar 0,134 yang artinya bahwa setiap peningkatan satu satuan kualitas produk, maka minat beli konsumen akan meningkat sebesar 0,134 kali terhadap pembelian produk bunga melati di Desa Talkandang dengan asumsi variabel lainnya tetap. Hal tersebut disebabkan oleh keindahan, keserasian, serta kesesuaian rangkaian dari produk bunga melati di Desa Talkandang, Sehingga akan mempengaruhi minat beli konsumen.

Hasil uji regresi linier berganda pada variabel kualitas produk (X1) terhadap koefisien regresi pada Tabel 5.33 diperoleh nilai t hitung sebesar 1,49 dengan nilai signifikansi sebesar 0,14 . Jika signifikan lebih lebih kecil atau sama dengan $(\leq 0,05)$ maka hipotesis diterima. Dari hasil penelitian diperoleh nilai signifikan pada variabel kualitas produk sebesar 0,14 > 0,05 maka disimpulkan hipotesis yang menyatakan "Kualitas produk berpengaruh signifikan terhadap minat beli produk bunga melati di Desa Talkandang, Kecamatan Situbondo, Kabupaten Situbondo" ditolak. Hasil penelitian ini menunjukkan bahwa variabel kualitas produk secara independen tidak berpengaruh signifikan terhadap minat beli konsumen akan produk bunga melati di Desa Talkandang pada tingkat kepercayaan $95 \%$.

Kenyataan yang diperoleh dari konsdisi di lapangan, para petani di Desa Talkandang kurang menjaga kualitas bunga melati yang mereka produksi. Hal tersebut terlihat jelas dari upaya petani yang sangat minim dalam memberi perlakuan pasca panen seperti tidak adanya tempat penyimpanan khusus sehingga warna produk kurang segar dan cepat layu. Selain itu pengemasan juga kurang diperhatikan dengan baik sehingga membuat produk bunga melati di Desa Talkandang tidak tahan lama dan mudah rusak. Karena fakta yang didapat dari kualitas produk bunga melati di Desa Talkandang kurang baik, sehingga variabel kualitas produk tidak berpengaruh secara signifikan terhadap minat beli konsumen.

\section{Kualitas Pelayanan}

Nilai koefisien kualitas pelayanan adalah sebesar 0,098 yang artinya bahwa setiap peningkatan satu satuan kualitas pelayanan maka akan meningkatkan minat beli konsumen sebesar 0,098 kali terhadap pembelian produk bunga melati di Desa Talkandang dengan asumsi variabel lainnya tetap. Hal tersebut disebabkan oleh kemampuan petani bunga melati dalam melayani konsumen.

Hasil uji regresi linier berganda pada variabel kualitas pelayanan (X2) terhadap koefisien regresi seperti pada Tabel 5.33 diperoleh nilai t hitung sebesar 1,06 dengan nilai signifikansi 0,29. Jika signifikan lebih kecil atau sama dengan $(\leq 0,05)$ maka hipotesis diterima. Hasil penelitian diproleh nilai signifikansi sebesar 0,29 >0,05. Maka dapat disimpulkan bahwa hipotesis yang menyatakan "Kualitas pelayanan berpengaruh 
signifikan terhadap minat beli produk bunga melati di Desa Talkandang, Kecamatan Situbondo, Kabupaten Situbondo" ditolak. Hasil penelitian ini menunjukkan bahwa secara independen variabel kualitas pelayanan tidak berpengaruh secara signifikan terhadap minat beli konsumen akan produk bunga melati di Desa Talkandang pada tingkat kepercyaan 95\%.

Variabel kualitas pelayanan tidak berpengaruh secara independen terhadap variabel minat beli konsumen dikarenakan pada variabel ini juga kurang diperhitungkan oleh para petani di desa talkandang sebab seluruh petani tidak menyediakan gedung atau ruangan khusus untuk melayani konsumen. Mereka biasa melayani konsumen di teras rumah atau ruang tamu, karena usahatani yang mereka jalankan tergolong skala kecil, sehingga mereka tidak mampu menyediakan bangunan khusus yang dibuat untuk kegiatan produksi/kantor. Di sisi lain, para petani di Desa Talkandang kurang menguasai tekhnologi dan cara mereka berkomunikasi kurang baik, sehingga itu menjadi hal lain yang berdampak kurang baiknya kualitas pelayanan yang diberikan pada konsumen.

\section{Harga}

Nilai koefisien harga adalah sebesar - 0,074 yang artinya bahwa setiap peningkatan satu satuan harga sebesar Rp 1, maka akan menurunkan minat beli konsumen sebesar 0,074 kali terhadap pembelian produk bunga melati di Desa Talkandang dengan asumsi variabel lainnya tetap. Hal tersebut sesuai dengan bunyi hukum permintaan yang mengatakan bahwa harga berbanding terbalik terhadap jumlah yang diminta, yaitu apabila harga suatu barang naik, maka jumlah barang yang diminta tersebut akan turun. Sebaliknya, bila harga barang tersebut turun maka jumlah barang yang diminta akan naik.

Hasil uji regresi linier berganda pada variabel harga (X3) terhadap koefisien regresi pada Tabel 5.33 diperoleh nilai t hitung sebesar $-0,83$ dengan nilai probabilitas sebesar 0,4 . Jika signifikan lebih lebih kecil atau sama dengan $(\leq 0,05)$ maka hipotesis diterima. Dari hasil penelitian diperoleh nilai signifikan pada variabel kualitas produk sebesar 0,4>0,05 maka disimpulkan hipotesis yang menyatakan "Harga berpengaruh signifikan terhadap minat beli produk bunga melati di Desa Talkandang, Kecamatan Situbondo, Kabupaten Situbondo" ditolak. Hasil penelitian ini menunjukkan bahwa secara independen variabel harga tidak berpengaruh secara signifikan terhadap minat beli konsumen terhadap produk bunga melati di Desa Talkandang pada tingkat kepercayaan $95 \%$.

Hasil uji t pada Variabel harga menunjukkan tidak ada pengaruh yang signifikan terhadap minat beli konsumen akan produk bunga melati di Desa Talkandang, hal itu disebabkan oleh harga yang ditetapkan oleh petani terhadap produk bunga melati yang mereka hasilkan masih terjangkau oleh konsumen. Jika harga produk dinaikkan, tidak terlalu mempengaruhi minat beli konsumen karena produk bunga melati bukan produk primer, tidak semua orang selalu membutuhkan produk tersebut.

\section{Inovasi Produk}

Nilai koefisien inovasi produk adalah sebesar 0,043 yang artinya bahwa setiap peningkatan satu satuan inovasi produk, maka akan menaikkan minat beli konsumen sebesar 0,043 kali terhadap pembelian produk bunga melati di Desa Talkandang dengan asumsi variabel lainnya tetap. Hal tersebut disebabkan oleh perubahan model bentuk yang dilakukan para petani terhadap produk bunga melati yang mereka tawarkan.

Hasil uji regresi linier berganda pada variabel inovasi produk (X4) terhadap koefisien regresi pada Tabel 5.33 diperoleh nilai t hitung sebesar 0,48 dengan nilai probabilitas sebesar 0,63. Jika signifikan lebih lebih kecil atau sama dengan $(\leq 0,05)$ maka hipotesis diterima. Dari hasil penelitian diperoleh nilai signifikan pada variabel kualitas produk sebesar 0,63 > 0,05 maka disimpulkan hipotesis yang menyatakan "Inovasi 
produk berpengaruh signifikan terhadap minat beli produk bunga melati di Desa Talkandang, Kecamatan Situbondo, Kabupaten Situbondo" ditolak. Hasil penelitian ini menunjukkan bahwa secara independen variabel inovasi peoduk tidak berpengaruh terhadap minat beli konsumen terhadap produk bunga melati di Desa Talkandang pada tingkat kepercayaan 95\%.

Dari temuan fakta dalam penelitian mengungkapkan bahwa para petani di Desa Talkandang masih belum optimal dalam mengembangkan usahatani yang mereka geluti, sebab produksi yang mereka hasilkan hanya sebatas bunga segar saja serta metode yang dipakai juga masih tradisonal. Tidak sampai pada level pengembangan atau pengenalan produk baru melalui diversifikasi produk, sebab bunga melati dapat diolah menjadi berbagai produk lain seperti bahan baku industri teh melati, obat herbal atau minyak atsiri sebagai bahan baku kosmetik.

\section{Ketersediaan Produk}

Nilai koefisien ketersediaan produk adalah sebesar 0,130 yang artinya adalah setiap peningkatan satu satuan ketersediaan produk maka akan menaikkan minat beli konsumen sebesar 0,130 kali terhadap pembelian produk bunga melati di Desa Talkandang dengan asumsi variabel lainnya tetap. Hal tersebut diakibatkan oleh kemudahan yang dirasa oleh konsumen dalam mendapat produk bunga melati tersebut.

Hasil uji regresi linier berganda pada variabel ketersediaan produk (X5) terhadap koefisien regresi pada Tabel 5.33 diperoleh nilai t hitung sebesar 1,17 dengan nilai probabilitas sebesar 0,24 . Jika signifikan lebih lebih kecil atau sama dengan $(\leq 0,05)$ maka hipotesis diterima. Dari hasil penelitian diperoleh nilai signifikan pada variabel kualitas produk sebesar 0,24 > 0,05 maka disimpulkan hipotesis yang menyatakan "Inovasi produk berpengaruh terhadap minat beli produk bunga melati di Desa Talkandang, Kecamatan Situbondo, Kabupaten Situbondo" ditolak. Hasil penelitian ini menunjukkan bahwa secara independen variabel inovasi produk tidak berpengaruh terhadap minat beli konsumen terhadap produk bunga melati di Desa Talkandang pada tingkat kepercayaan $95 \%$.

Tidak adanya pengaruh signifikan yang disebabkan oleh variabel ketersediaan produk terhadap minat beli konsumen akan produk bunga melati di Desa Talkandang lantaran para petani lebih sering tidak menyanggupi permintaan konsumen berkaitan lokasi yang terlalu jauh, jumlah permintaan yang telalu banyak dan waktu permintaan yang terlalu singkat atau mendadak karena usahatani yang dijalankan masih dalam skala kecil, sehingga produksi bunga melati yang dihasilkan masih sangat terbatas.

\section{Hubungan Emosional}

Nilai koefisien hubungan emosional adalah sebesar 0,215 yang artinya adalah setiap peningkatan satu satuan hubungan emosional maka akan menaikkan minat beli konsumen sebesar 0,215 kali terhadap pembelian produk bunga melati di Desa Talkandang dengan asumsi variabel lainnya tetap. Hal itu lantaran konsumen merasakan adanya hubungan emosional yang baik dengan para petani selama melakukan transaksi.

Hasil uji regresi linier berganda pada variabel hubungan emosional (X6) terhadap koefisien regresi pada Tabel 5.33 diperoleh nilai t hitung sebesar 0,24 dengan nilai probabilitas sebesar 1,48. Jika signifikan lebih lebih kecil atau sama dengan $(\leq 0,05)$ maka hipotesis diterima. Dari hasil penelitian diperoleh nilai signifikan pada variabel kualitas produk sebesar 1,48 > 0,05 maka disimpulkan hipotesis yang menyatakan "Hubungan emosional berpengaruh signifikan terhadap minat beli produk bunga melati di Desa Talkandang, Kecamatan Situbondo, Kabupaten Situbondo" ditolak. Hasil penelitian ini menunjukkan bahwa secara independen variabel hubungan emosional tidak berpengaruh terhadap minat beli konsumen terhadap produk bunga melati di Desa Talkandang pada 
tingkat kepercayaan 95\%.

Pada variabel ini juga tidak memberikan pengaruh yang signifikan secara parsial terhadap minat beli konsumen akan produk bunga melati di Desa Talkandang disebabkan oleh para petani kurang memberi perhatian secara pribadi dari segi memahami kebutuhan konsumen, selain itu Brand Personality yang dihasilkan petani di Desa Talkandang masih lemah. Sehingga pengaruhnya terhadap minat beli konsumen akan produk tersebut juga lemah karena hasrat mereka kurang terpuaskan melalui hubungan emosional yang terjalin antara petani dan konsumen. Karena menurut Gobe (2005) hubungan emosional memfokuskan pada aspek yang paling mendesak manusia, yaitu keinginan memperoleh kepuasan material dan mengalami pemenuhan emosional.

\section{KESIMPULAN}

Berdasarkan hasil analisis dan pembahasan yang telah dilakukan, maka kesimpulan dari hasil penelitian ini adalah variabel-variabel dalam kepuasan konsumen berupa kualitas produk, kualitas pelayanan, harga, inovasi produk, ketersediaan produk dan hubungan emosional tidak berpengaruh terhadap minat beli konsumen akan produk bunga melati di Desa Talkandang secara parsial. Keenam variabel bebas tersebut mempengaruhi minat beli hanya secara simultan/bersama-sama sebesar 35,3\%, sedangkan sisanya sebesar 64,7 \% dijelaskan oleh variabel lain di luar penelitian ini.

\section{REFERENSI}

Bachtiar. (2011). Analisa Faktor-Faktor yang Mempengaruhi Kepuasan Mahasiswa dalam Memilih Politeknik Sawunggalih Aji Purworejo. Dinamika Sosial Ekonomi Vol 7 No. 1

Ferdinand. 2002. Metode Penelitian Manajemen : Pedoman penelitian untuk Skripsi, Tesis, dan Desertasi Ilmu Manajemen, Universitas Diponegoro: Semarang.

Ghozali. 2005. Analisis Multivariat dengan Program SPSS. Edisi Ketiga. UNDIP: Semarang.

Gobe, Marc. 2005, Emotional Branding.

Erlangga: Jakarta.

Gujarati, Damodar N. 2006. Ekonometrika Dasar. Erlangga: Jakarta.

Harini. 2008. Makroekonomi Pengantar. PT Gramedia Pustaka: Jakarta.

Husein Umar. 2002. Riset Pemasaran dan Perilaku Konsumen. Gramedia Pustaka Utama: Jakarta.

Irawan. 2008. Sepuluh Prinsip Kepuasan Konsumen. Elex Media Komputindo Kelompok Gramedia: Jakarta.

Kotler dan Amstrong. 2008. Prinsip - Prinsip Pemasaran. Erlangga: Jakarta.

Kotler dan Amstrong. 2012. Principles of Marketing. PT. Gramedia Pustaka Utama: Jakarta.

Kotler dan Keller. 2009. Menajemen Pemasaran, Edisi Ketigabelas. Erlangga: Jakarta.

Kotler, Philip dan Kevin Lane Keller. 2008. Manajemen Pemasaran, Edisi Kedua Belas. PT. Indeks: Jakarta.

Sugiyono. 2000. Statistik Untuk Penelitian. CV. Alfabeta: Bandung. 